\title{
COMPARATIVE PRELIMINARY UNIT COSTS ANALYSIS OF THE OPERATION OF PASSENGER CARS WITH COMBUSTION ENGINES AND FUEL CELL VEHICLES POWERED BY HYDROGEN
}

\author{
Wojciech Gis, Jerzy Waśkiewicz, Maciej Menes, Maciej Gis \\ Motor Transport Institute \\ Jagiellonska Street 80, 03-301 Warsaw, Poland \\ tel.: +4822 4385400,fax: +48224385401 \\ e-mail:wojciech.gis@its.waw.pl,jerzy.waskiewicz@its.waw.pl \\ maciej.menes@its.waw.pl,maciej.gis@its.waw.pl
}

\begin{abstract}
The article presents political and legal aspects regarding the recommendation for the development of hydrogen technology in the economy and in transport. The development of electric cars with hydrogen-powered fuel cells, which took place in recent years in the world, has been outlined. The principles of calculation of average vehicle operating costs applicable in the transport economics are discussed. The estimated average unit operating costs of a statistical passenger car using conventional energy carriers, estimated in the studies of the Motor Transport Institute are quoted. The assumptions and results of the estimation of the average cost per 1 vehicle-kilometre of the electric passenger car's mileage (BEV) have been presented, as well as the assumptions and results of the estimation of the average unit operating costs of a hydrogen powered passenger car (FCEV). The average unit costs of the mileage of these vehicles have been compared. The predictions regarding the future changes in the average prices of FCEV vehicles have been cited and the average unit costs of operating electric cars with fuel cells by the 2050 have been estimated. The project of administrative support for the development of low-emission transport in Poland was indicated.
\end{abstract}

Keywords: passenger cars, fuel cells, hydrogen, costs

\section{Introduction}

Seeking new energy carriers' alternative to fossil fuels used in the economy is the effect among the others - of the Paris Agreement in result of which the ratifying states agreed to aim at reducing greenhouse gases, and thus to counteract adverse climate changes in the world. According to the Fuel Cells and Hydrogen Joint Undertaking, one of the ways to accomplish ambitious environmental goals is to develop hydrogen technologies in the economy.

According to various analyses, the processes of decarbonisation and global energy transformation in worldwide economies in the forthcoming decades will involve at least four areas: power engineering, transport, heating and industry.

The advantages of hydrogen as an energy carrier is - among the others - the possibility of storing energy, contrary to energy from renewable sources such as solar and wind energy whose output is characterised by considerable instability in supply. One of the known ways of producing hydrogen is the process of water electrolysis.

In the world, transport the development of the hydrogen technology for fuel cells producing electrical energy powering batteries and then used by electric motors in vehicles first involved passenger cars.

As far as the legal aspect is concerned, in the EU member states the development of the hydrogen technology for the motor transport is recommended among others in the Directive 2014/94/EU of the European Parliament and Council of 22 October 2014. The document stipulates that EU member states should successively develop the HRS infrastructure on their territories and provide the possibility of passage for the hydrogen-fuelled vehicles between member states. 


\section{Hydrogen in motor transport}

At present, the development of innovation in transport concerns among the others hydrogen technologies. The reason of interest in this is, on the one hand, the concern for the purity of air polluted by the exhaust fumes from the transport means with internal combustion engines, and on the other hand the desire to increase energy security of individual countries by reducing their dependence on the import of energy raw material, which the crude oil is.

The development of hydrogen utilization in transport, including the road transport, will depend on the technology of fuel cells powered by this element.

Fuel cell vehicles (FCEV) are in fact electric vehicles equipped additionally with electric batteries. Unlike typical electric vehicles (BEV), they do not require charging via an external power network. The advantage of FCEV is its longer driving range compared to BEV, owing to the high "density" of the stored energy. For example, hydrogen compressed to 300 bars has energy "density" of $120 \mathrm{MJ} / \mathrm{kg}$, while in the lithium - ion batteries it is equal to $0.5 \mathrm{MJ} / \mathrm{kg}$. In the case of petrol, it is approx. $43 \mathrm{MJ} / \mathrm{kg}$.

Currently, in some countries of the world (in particular: Japan, the US, highly developed EU member states) hydrogen for powering fuel cell vehicles is used in the transport system. In Japan, which manufacturers and offers hydrogen-fuelled vehicles on the market, approx. 2,500 such vehicles are used. There are in the US roughly 4,500 and in Germany - 500. The distribution network of this energy carrier is being developed and major motor companies, e.g. Hyundai, present new fuel-cell vehicles [9].

Work is pending in the laboratories worldwide on improving the technology of electric means of transport powered with fuel cells. Scientific and technical sessions at international conferences reflect interest among scientific milieus in the topic and the broadly understood practical aspects of transport. A good example is the "Improvement of Emissions and Effects of Electric and Fuel Cell Vehicles, Busses and Trains" session at the TRA conference 2018 [5].

The hydrogenization of economy is an issue drawing attention also in Poland as reflected by the conference "Time for Hydrogen", which addressed not only the use of hydrogen in transport but also in other industries [3]. Particularly important is the technical global progress as regards the development of fuel cells. The barriers existing in that development can be overcome within several years. For instance, a fuel cell with capacity up to $5 \mathrm{~kW}$ costs presently approx. EUR 25 thousand. It is expected that soon a fuel cell with capacity up to $25 \mathrm{~kW}$ may cost EUR 4-5 thousand, which would become a vital economic incentive for the development of the hydrogen technology.

The topic taken up at the Motor Transport Institute, jointly with the Institute of Industrial Chemistry [10] corresponds, with this current subject of the use of innovative energy carriers in transport. One of its tasks concerns the attempt to make economic evaluation of the use of hydrogen technology in the road transport under Polish conditions.

\section{Estimates of average unit costs of operating passenger cars}

Poland has so far no experience in operating fuel cell vehicles powered by hydrogen. For this reason, the knowledge of the average unit costs of operating combustion engine powered passenger cars was used for comparison with calculated assumption-based average costs of operating fuel-cell vehicles powered by hydrogen.

According to the studies of average unit costs of using passenger cars performed by the Motor Transport Institute in 2019 [8] those costs vary depending on the category of vehicle - its make, model, age and annual mileage.

The cost analyses performed have taken into account both costs that depend on the mileage and costs that depend on the period during which a vehicle is possessed.

Costs that depend on the vehicle's mileage: 
- costs of fuel,

- costs of electrical energy (in the case of BEV),

- costs of service within the scope recommended by car manufacturers,

- costs of tyres.

- costs that depend on the period in which a vehicle is in possession:

- costs relating to the loss of vehicle's market value,

- costs of motor vehicle insurances,

- costs of technical inspections.

In the quoted calculations of the average costs per 1 vehicle-kilometre of mileage of the passenger cars, for each of the specified categories, the average annual mileage of vehicles have been taken into account, based on the Central Register of Vehicles data (CRV). The average costs per 1 vehicle-kilometre shown below according to the studies of the Motor Transport Institute represent costs of a statistical passenger car registered in Poland, from the production years 2008-2017. According to CRV data, the number of passenger cars registered in Poland and manufactured in the years 2008-2017 was equal to approx. 4.3 million. The calculated average annual mileage of a statistical passenger car from those production years comes to roughly $14,800 \mathrm{~km}$.

Based on the assumptions, the average cost per 1 vehicle-kilometre of a statistical passenger car equipped with a combustion engine and used from the very beginning for up to 10 years was equal to $1.10 \mathrm{PLN} / \mathrm{km}$.

Comparable average costs per 1 vehicle kilometre of an electrical vehicle (BEV) Nissan Leaf [8], calculated based on the assumptions, was equal to approx. 1.50 PLN $/ \mathrm{km}$. Attention should be given to the fact that with low energy density in the batteries of electric vehicles compared to the energy density in crude-oil fuels or compared to the density of hydrogen energy, BEVs will be usually used on the short-distance journeys. This gives an advantage to vehicles with conventional drive systems and in the future to the fuel-cell electric vehicles.

In the case of fuel-cell electric vehicles (FCEV), estimates of average unit costs of operation were made based on the following assumptions:

- the average price of an electric fuel-cell passenger car will amount to c.a. 284 thousand PLN (the price of Toyota Mirai on the German market [7] is equal to approx. 66 thousand EURO),

- the average loss of value of a vehicle within a 10 years period of operation will come to approx. 260 thousand PLN,

- the average price per $1 \mathrm{~kg}$ of hydrogen will be EUR 9.5 [6],

- the average consumption of hydrogen will be equal to approx. $1 \mathrm{~kg}$ of hydrogen per $100 \mathrm{~km}$,

- the average annual mileage of the vehicle will be 14.8 thousand $\mathrm{km}$,

- and the average unit costs of tyres, technical service and car insurance will be at the level of unit costs of vehicles with conventional engines [8].

According to the above assumptions, the average cost per 1 vehicle-kilometre of mileage for a fuel-cell electric vehicle has been estimated presently at approx. 2.45 PLN/km (Tab. 1).

The cost would be 2.2 times greater compared to the average unit cost of a statistical passenger car produced in the years 2008-2017 in Poland, equipped with an internal combustion engine and approx. 63\% greater compared to average unit costs of Nissan Leaf electric vehicle.

In the estimated (up-to-date) assumptions adopted of the average costs of the use of fuel-cell passenger cars the dominant are the costs of the vehicle's loss of market value in the structure of costs per 1 vehicle-kilometre of mileage and account for approx. 70\% (Fig. 1).

However, with an increase in the production and sale of fuel-cell passenger cars the costs of their production and the market price can be expected to drop. The forecasts are as follows: 2020 - EUR 25,200; 2025 - EUR 22,600; 2030 - EUR 20,000; 2040 - EUR 18,700; 2050 - EUR 18,000 [1]. If these forecasts were to come true, the average unit costs of use of fuel-cell vehicles would decrease (Tab. 2). 
Calculations made based on the adopted assumptions prove that a reduction in the price of fuelcell passenger cars within a period of 30 years would have an impact on the average costs per 1 vehicle-kilometre in such cars on a level similar to the costs of combustion-engine vehicles used now.

Tab. 1. Simplified calculation of the average costs of 1 vehicle-kilometre of mileage of an electric car with hydrogen powered fuel cells, for the 10 years since new

\begin{tabular}{|l|c|c|}
\hline \multicolumn{3}{|c|}{ The costs dependent on the time of the vehicle ownership } \\
\hline The average price of a new one in Euro & euro & 66000 \\
\hline The average price of a new one in PLN & PLN & 283800 \\
\hline Estimated average market price after 10 years & PLN & 24000 \\
\hline Loss of market value & PLN & 259800 \\
\hline Insurance package costs & PLN & 28000 \\
\hline The costs of the technical examination & PLN & 700 \\
\hline Total costs dependent on the time of the vehicle ownership & PLN & 288500 \\
\hline \multicolumn{2}{|c|}{ Costs depending on the mileage } & $\mathrm{km}$ \\
\hline Average annual mileage & $\mathrm{kg} / 100 \mathrm{~km}$ & 14800 \\
\hline Average fuel consumption per 100 km of mileage & euro/kg & 1 \\
\hline The average price of fuel in Euro & PLN/euro & 9.5 \\
\hline Average Euro exchange rate & PLN/kg & 40.3 \\
\hline The average price of fuel in PLN & PLN & 60458 \\
\hline Fuel costs & PLN & 8300 \\
\hline Maintenance costs & PLN & 5200 \\
\hline The costs of tire sets and replacement costs & PLN & 73958 \\
\hline Total costs dependent on the mileage of the vehicle & PLN & 362458 \\
\hline Total vehicle operating costs over 10 years & PLN/km & 2.45 \\
\hline The average cost of 1 vehicle-kilometre of mileage & &
\end{tabular}

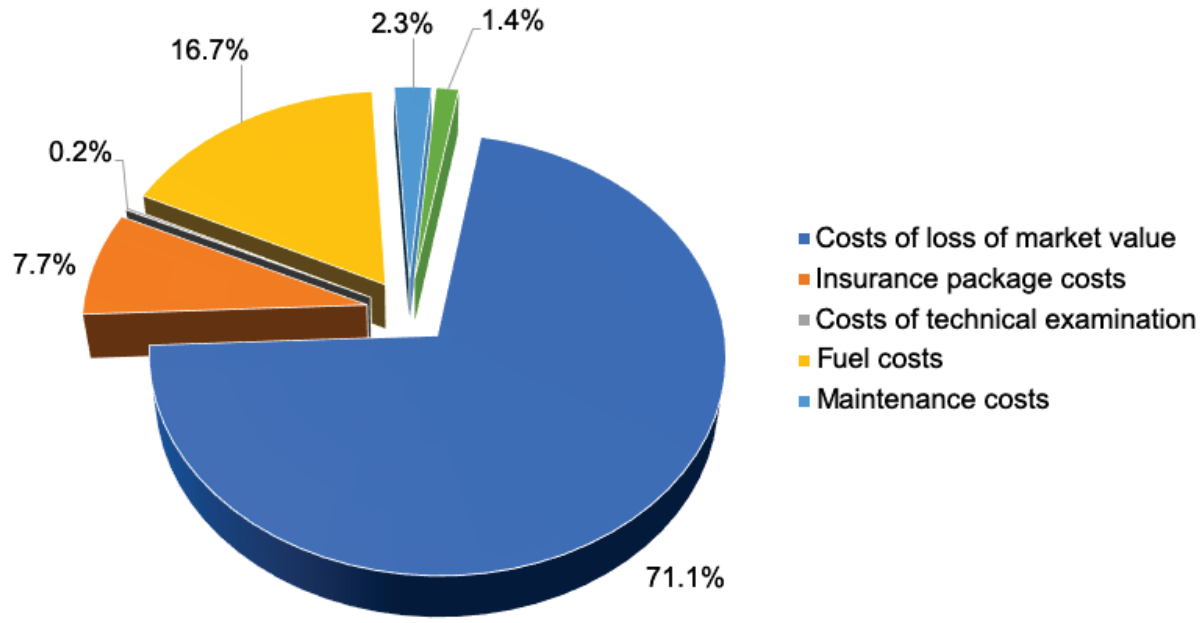

Fig. 1. Estimated structure of the average cost of 1 vehicle-kilometre of mileage of a passenger car with hydrogen-powered fuel cells [\%]

The formulated conclusions following comparisons of the future average unit costs of the use of vehicles with conventional combustion engines and fuel-cell vehicles using hydrogen correspond to the forecasts of other authors [2]. It is expected that " .... as early as in 2025-2030 
the overall costs of purchase and use of a hydrogen-fuelled vehicle should be greater by just $10 \%$ than similar costs of a vehicle with a traditional combustion engine, and the difference will tend to drop together with the increased intensity in the use of the vehicle. The costs of a hydrogen-fuelled vehicle will most likely become fully competitive with those of passenger cars with a conventional drive system in the years 2030-2040".

Tab. 2. Estimates of the average costs per 1 vehicle-kilometre of mileage of the passenger car with hydrogen-powered fuel cells over 10 years from now until the 2050

\begin{tabular}{|c|c|c|c|c|c|c|c|}
\hline \multicolumn{3}{|c|}{ The costs dependent on the time of the vehicle ownership } & \multicolumn{5}{|c|}{ Predictions } \\
\hline & & 2019 & 2020 & 2025 & 2030 & 2040 & 2050 \\
\hline The average price of a new one in Euro & euro & 66000 & 25200 & 22600 & 20000 & 18700 & 18000 \\
\hline The average price of a new one in PLN & PLN & 283800 & 108360 & 97180 & 86000 & 80410 & 77400 \\
\hline $\begin{array}{l}\text { Estimated average market price after } \\
10 \text { years }\end{array}$ & PLN & 24000 & 20000 & 17500 & 15000 & 12500 & 10000 \\
\hline Loss of market value & PLN & 259800 & 88360 & 79680 & 71000 & 67910 & 67400 \\
\hline Insurance package costs & PLN & 28000 & 28000 & 28000 & 28000 & 28000 & 28000 \\
\hline The costs of the technical examination & PLN & 700 & 700 & 700 & 700 & 700 & 700 \\
\hline $\begin{array}{l}\text { Total costs dependent on the time } \\
\text { of the vehicle ownership }\end{array}$ & PLN & 288500 & 117060 & 108380 & 99700 & 96610 & 96100 \\
\hline \multicolumn{8}{|c|}{ Costs depending on the mileage } \\
\hline Average annual mileage & $\mathrm{km}$ & 14800 & 14800 & 14800 & 14800 & 14800 & 14800 \\
\hline $\begin{array}{l}\text { Average fuel consumption per } 100 \mathrm{~km} \\
\text { of mileage }\end{array}$ & $\mathrm{kg} / 100 \mathrm{~km}$ & 1 & 1 & 1 & 1 & 1 & 1 \\
\hline The average price of fuel in Euro & euro/kg & 9.5 & 9.5 & 9.5 & 9.5 & 9.5 & 9.5 \\
\hline Average Euro exchange rate & PLN/euro & 4.3 & 4.3 & 4.3 & 4.3 & 4.3 & 4.3 \\
\hline The average price of fuel in PLN & $\mathrm{PLN} / \mathrm{kg}$ & 40.85 & 40.85 & 40.85 & 40.85 & 40.85 & 40.85 \\
\hline Fuel costs & PLN & 60458 & 60458 & 60458 & 60458 & 60458 & 60458 \\
\hline Maintenance costs & PLN & 8300 & 8300 & 8300 & 8300 & 8300 & 8300 \\
\hline $\begin{array}{l}\text { The costs of tire sets and replacement } \\
\text { costs }\end{array}$ & PLN & 5200 & 5200 & 5200 & 5200 & 5200 & 5200 \\
\hline $\begin{array}{l}\text { Total costs dependent on the mileage } \\
\text { of the vehicle }\end{array}$ & PLN & 73958 & 73958 & 73958 & 73958 & 73958 & 73958 \\
\hline $\begin{array}{l}\text { Total vehicle operating costs over } \\
10 \text { years }\end{array}$ & PLN & 362458 & 191018 & 182338 & 173658 & 170568 & 170058 \\
\hline $\begin{array}{l}\text { The average cost of } 1 \text { vehicle-kilometre } \\
\text { of mileage }\end{array}$ & $\mathrm{PLN} / \mathrm{km}$ & 2.45 & 1.29 & 1.23 & 1.17 & 1.15 & 1.15 \\
\hline
\end{tabular}

The comparison of average costs per 1 vehicle-kilometre of mileage of the passenger cars using conventional energy carriers and the average unit costs of operating fuel-cell vehicles powered by hydrogen, points towards the price of a new fuel-cell passenger car, which could be a competitive one for the development of an innovative technology in transport based on hydrogen as an energy carrier. The price for a medium class passenger car with a traditional combustion engine in current conditions (the $1^{\text {st }}$ quarter of 2019) would be equal to c.a. 70-80 thousand PLN. Therefore, presently the difference between the price of a new fuel-cell passenger car and the price of such car - from the point of view of a decision regarding the purchase of such vehicle - is roughly 200 thousand PLN 
Taking into account, the economic aspect of operating cars incorporating innovative energy carriers, it should be added that the draft ordinance of the Minister of Energy regarding specific conditions for granting and settling support under the Low-Emission Transport Fund specifies the level of support and maximum amounts that can be allocated from the fund per vehicle. The draft ordinance stipulates that the expected amounts be supposed to reduce somewhat the difference between current prices of vehicles using alternative fuels and the prices of presently offered combustion-engine vehicles [4]. In addition, the maximum support in the case of an electric vehicle is proposed to be $30 \%$ of the qualified costs and no more than PLN 36 thousand for a vehicle. As regards FCEVs fuelled with hydrogen, the support would account for $30 \%$ of qualified costs and no more than PLN 75 thousand for a vehicle.

\section{Summary}

The estimates of average costs per 1 vehicle-kilometre of mileage of the selected types of FCEVs fuelled with hydrogen reflect the scale of variation in costs compared to the costs of vehicles with a conventional engine. It is likely that over time and with the technological progress but above all as a result of growing use of fuel cell vehicles subject also to the development of HRS infrastructure, those proportions will be smaller to the advantage of the innovative hydrogen technology. Actions that will stimulate that technology in the initial phases - aiming at protecting air against hazardous emissions from vehicles with conventional engines, and independence from crude oil exporters - may include - among the others - the use of political tools ensuring various preferences to the users of those vehicles. Moreover, it cannot be excluded that actions supporting the gradual implementation of the hydrogen technology in motor transport will involve additional financial burdens or administrative inconveniencies for the users of vehicles with combustion engines.

\section{References}

[1] Harrison, P., Fuelling Europe's Future, Clepa, Eurelectric, Eurobat, European Climate Foundation, Nissan, SSE, Transport and Environment, Cambridge Econometrics, Ricardo AEA, Element Energy, 2013.

[2] Hydrogen scaling up. A sustainable pathway for the global energy transition, Hydrogen Council, November 2017.

[3] Time for Hydrogen Conference, Warsaw University of Technology, 25 April 2019.

[4] www.nowa-energia.com.pl, Propozycje ME: do 36 tys. zt dopłaty do samochodu elektrycznego, of 2019.02.15.

[5] The $7^{\text {th }}$ Transport Research Arena conference, A digital era for transport - solutions for society, economy and environment, 16-19 April 2018, Vienna.

[6] www.spiderweb.pl Price of hydrogen at TOTAL station in Berlin in May 2015.

[7] www.toyota-kellr.de of April 2019 in Germany the price of Toyota Mirai - approx. 66890,euro, according to www.thecarconnection.com of 14 March 2019 approx. USD 58.500.

[8] Waśkiewicz, J., Kamińska, E., Zysińska, M., Menes, M., Pawlak, P., Balke, M., Oszacowanie średnich jednostkowych kosztów eksploatacji reprezentatywnych dla parku eksploatowanego $w$ Polsce marek $i$ modeli samochodów osobowych, motocykli $i$ motorowerów wedtug wybranych kryteriów, praca ITS nr 1125/ZBE/18, Warsaw, March 2019, Expert opinion provided for the purpose of the Ministry of Infrastructure.

[9] VISION mobility, No. 3/2019, Test Hyundai Nexo, 5 May 2019.

Manuscript received 29 July 2019; approved for printing 29 November 2019 